\title{
IMPACT OF FRAME ARCHITECTURE ON ROAD TRAFFIC SAFETY MANAGEMENT
}

\section{WPLYW ZASTOSOWANIA ARCHITEKTURY FRAME NA ZARZĄDZANIE BEZPIECZEŃSTWEM RUCHU DROGOWEGO}

\author{
Sylwia Szewczyk, Mirosław Siergiejczyk, Karolina Krzykowska \\ Warsaw University of Technology, Politechnika Warszawska
}

\begin{abstract}
The article presents issues associated with ITS and their influence on the safety and efficiency of road traffic. Each system to be implemented at a specified location is thoroughly analysed and defined. The architecture defining process utilised the FRAME architecture based on an example of a service concerning the transfer of information on environmental conditions.
\end{abstract}

Keywords: ITS, intelligent transport systems, road traffic safety, FRAME architecture

Streszczenie: $W$ artykule zaprezentowano zagadnienia zwiazane z inteligentnymi systemami transportowymi (ITS) $i$ ich wptywem na bezpieczeństwo i efektywność ruchu drogowego. Każdy system, który ma być wdrożony w określonej lokalizacji, jest doktadnie analizowany $i$ definiowany. Proces definiowania architektury wykorzystuje architekturę FRAME na przykładzie ustugi dotyczacej przekazywania informacji o warunkach środowiskowych.

Stowa kluczowe: ITS, inteligentne systemy transportowe, bezpieczeństwo ruchu drogowego, architektura FRAME 
Impact of FRAME architecture on road traffic safety management

Wplyw zastosowania architektury FRAME na zarzadzanie bezpieczeństwem ruchu..

\section{Introduction}

A vigorous development of the road infrastructure increases the attractiveness of mobility, thus, influencing the increase of traffic volume. It is a positive phenomenon from the economic point of view, however, it poses a threat of road accidents and increases environmental pollution. Due to the above, governments and organisations (international, national, local government) are increasingly forced to create traffic management systems. The development of such systems must be coherent with the concept of sustainable development, i.e., influence the increase of their functioning efficiency, while decreasing negative effects of transport development. A solution which contains these features are Intelligent Transport Systems, which are a set of tools based on IT, ICT, electronics, and control technologies, for which the main priority is to raise the operability of the existing infrastructure, without the need for modification and further expansion. Thank to being innovative, they increase the road capacity, improve road safety and natural environment quality, while increasing travelling comfort. Vast possibilities and the resulting implementation benefits of these systems influence their selection by different countries [8].

The main aim of this paper is to present the application of the FRAME method for defining the functional architecture of the service "Transmitting environmental information to the drivers". Moreover, the article describes the aspects of the ITS impact on the improvement of the road traffic efficiency and safety.

\section{Impact of ITS services on road transport safety and efficiency}

A more in-depth analysis of the ITS app usually reveals the integration of studies from many scientific fields (e.g. Artificial Intelligence, human factors, road traffic engineering, etc.), which enable the development of many solutions to existing problems associated with road traffic safety. ITS implementation impacts road traffic in most countries around the world through:

- Increasing the general road traffic system effectiveness - the impact of ITS on efficiency can be seen by, for example, increased capacity, availability and customer service, etc. It is possible thanks to traffic management systems on highways and the systems directing vehicles to alternative routes (via the use of variable message signs) and the use of electronic toll collection systems

- Significant contribution to environmental protection and energy saving - the impact of ITS on the quality of the environment can be seen by, for example, reduced emissions, noise level and the pollution level in the atmosphere. ITS manages traffic in such a way, as to contribute to decreasing exhaust gas emissions by, e.g., implementation of the "Green Wave."

- Increasing the efficiency of transport systems - the impact of ITS on the efficiency can be measured economically, in terms of, e.g., operating costs.

- Improving traffic safety - the impact of ITS on road traffic safety can be identified, primarily, by decreasing the number of road incidents and a change in the effects and types of accidents [1]. An example confirming this statement is shown in figure 1, which presents a decreasing number of road incidents after implementing Intelligent Transport Systems. 


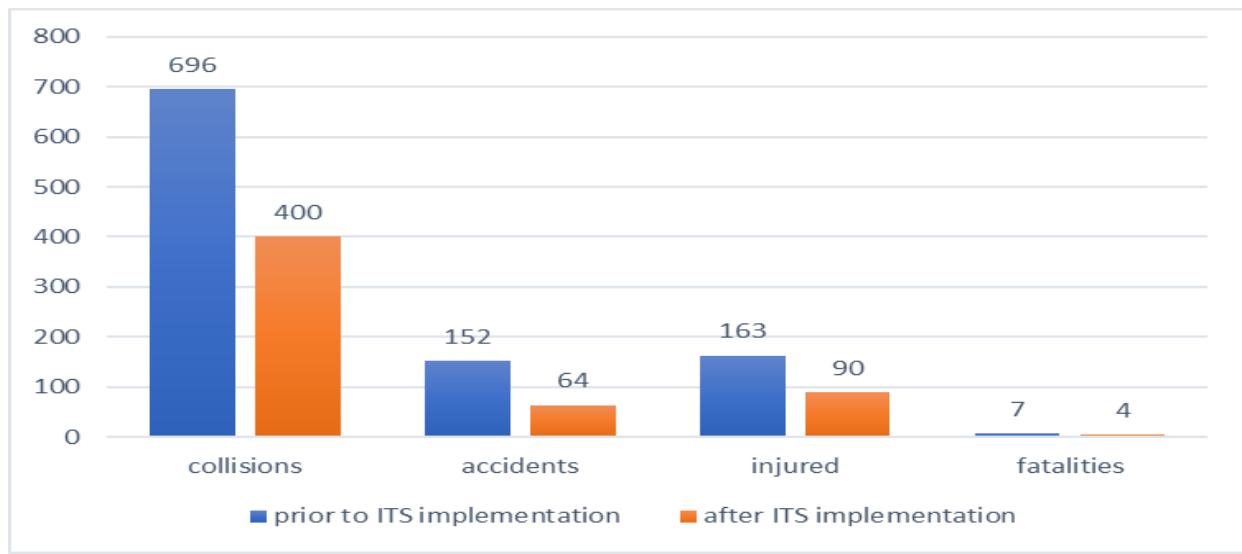

Fig. 1 Road safety assessment on provincial roads in Matopolska (own elaboration acc. to [8]).

In accordance with the road incident analysis conducted by the Provincial Road Authority in Kraków [8], during the ITS post-implementation period, a decrease in the number of collisions by about $42 \%$, the number of accidents by $58 \%$, the number of injured people by $45 \%$ and the fatalities by $42 \%$ was recorded.

The impact of ITS services and the associated modules on the road traffic safety can be considered in the functional, logical, or physical aspects. The functional aspect, involves considering the impact of services and groups of services on the behaviour of road users and the homogenisation of traffic flow, which contribute to a change in the RTS level, characterised by a reduction of a traffic hazard risk [5]. Improving safety in the logical context, refers to improving the cooperating of road administrators with emergency services, as well as actions contributing to the reduction accident effects (e.g. shortening the accident response time, incident detection). The RTS level is impacted also by the application of ITS services in private vehicles (e.g. monitoring the condition of a driver). The physical aspect, which includes functional reliability of ICT devices and systems is also of significant importance to road traffic safety.

\section{FRAME architecture}

The description of the FRAME architecture can be defined in many ways; however, the essences and sense remain the same. ITS architecture is a conceptual project, which determines the structure and behaviour of an integrated intelligent transport system (ITS). It is a set of standards concerning logical, physical and communication links between elements of the system [2]. In Europe (as well as in Poland), this architecture is called the European ITS Framework Architecture.

The ITS architecture has an extensive structure; however, it is significant for the implementation of ITS services. 
Impact of FRAME architecture on road traffic safety management

Wphyw zastosowania architektury FRAME na zarzadzanie bezpieczeństwem ruchu..

The main elements are distinguished and described below:

I. Stakeholder Aspiration List - contains the goals and needs of persons involved in ITS implementation. The Stakeholders (entities) are the users, public entities, service operators and providers. Aspirations are then formulated into simple statements, which constitute the User Needs.

II. User needs

III. Functional (Logical) Architecture of the System - a set of diagrams and specifications presenting functions and processes necessary to satisfy the user needs. The FRAME functional architecture includes the following elements:

- Function groups and functions - the FRAME architecture includes 9 function groups: electronic toll collection system, crisis managements and traffic safety, traffic management, public transport management, advanced driver assistance systems, information systems for travellers, support for surveillance and law enforcement services, and fleet management in freight transport. Functionality is divided into function in each functional area. They are classified into high (complex) and low level functions.

- Data flows - they are a connection between the functions, data repositories and terminators.

- Data depot (repository) - represented on the data flow diagram as a cylinder, means places, where data is stored between processes, which operate on it.

- Terminators - these are objects located outside of the architecture, connected with the functions via data flows. The terminators define groups, which consist of actors and have own, unique values.

IV. Physical Architecture - contains technologies and solutions, which enable the flow of information. Functions are assigned to organisational units at this stage. A unit may be a subsystem, which, in turn, may be divided into modules and databases.

V. Communication Architecture - is an analysis of communication requirements and connections between the arranged Physical Architecture elements, meaning, it determines the means of exchanging information between the elements of the Traffic Management System and external entities.

VI. Other Perspectives, e.g. Organisational/Entrepreneurial Perspective, describing business relations between organisations or the Information Perspective, ensuring formulas of data sets [6].

\section{Concept of implementing the ITS service using the FRAME architecture}

The project was executed for a service "Transmitting environmental information", which is significant from the point of view of road traffic efficiency and safety. Two tools of the FRAME Architecture were used for the project:

- Browsing Tool - a tool, which enables browsing, allows a user to study the FRAME architecture structure at each detail level and to acquire every element in it [4]. 
- Selection Tool - enables selecting elements of logical architecture, ensures support for a user in selecting a consistent subset of the FRAME architecture, corresponding the needs of specific users.

The project involved reviewing the user needs, matching them with relevant functionalities, and assigning terminators and actors.

\section{Goal of the project}

The goal of this project is to present the operation of a tool called FRAME Selection Tool during the creation of selected elements of the ITS Architecture, which is a subset chosen from a set of elements of the European ITS Framework Architecture and to present the impact of its application on road traffic safety. The service of "Transmitting environmental information to the drivers" plays a significant role in ensuring road traffic safety. Environmental conditions are one of the factors influencing road traffic. The occurrence of adverse weather conditions may significantly impact the decrease of the safety level on main roads, as well as the network of city streets (increased risk of accidents), hence, the level of reliability of the transport network. Weather phenomena impact both, the condition of the infrastructure, as well as driver behaviour (acceleration, movement speed, distance between the vehicles), therefore, changing the nature of road traffic [7]. The service enables detailed determination of the content and manner of the presented environmental information. The information on ambient temperature, icing, fog, rain fall can be of particular importance, since they may impact driving speed, distance between vehicles, as well as traffic efficiency, which largely depends on driver behaviour.

\section{Stakeholder Aspirations}

A number of aspirations was distinguished, which are a guide for particular groups/persons involved in ITS implementation. Providing information, which will influence road safety is crucial:

- end users will be able to receive information about the current and predicted ambient temperature, icing, fog, precipitation;

- end users will be able to receive information prior to the trip on a planned route;

- end users will be able to receive information about the exceeded air pollution level and be directed onto other routes accordingly;

- end users will be able to adjust their speed depending on the conditions on the road;

- end users will be able to adjust the distance between the vehicles, depending on weather conditions. 
Impact of FRAME architecture on road traffic safety management

Wplyw zastosowania architektury FRAME na zarzadzanie bezpieczeństwem ruchu..

\section{User needs}

On the basis of the stakeholder aspiration list, a list of user needs and corresponding functions were determined (Tab. 1). The user needs were selected out of a group concerning traffic management (group 7). Needs from the following groups, were selected using the Selection Tool software out of the available user needs:

1) 7.1.0 Objectives: need no. 7.1.0.4,

2) 7.1.1 Monitoring: need no. 7.1.1.6, 7.1.1.7, 7.1.1.8,

3) 7.1.2 Planning: need no. 7.1.2.5, 7.1.2.6,

4) 7.1.5 Exceptions management: need no. 7.1.5.9,

5) 7.5.1 Traffic Flow Optimisation: need no. 7.5.1.3,

6) 7.6.2 Enhanced Route Guidance and Navigation: need no. 7.6.2.4, 7.6.2.6.

Tab. 1 List of user needs and corresponding functions.

\begin{tabular}{|c|c|c|c|}
\hline $\begin{array}{l}\text { User } \\
\text { needs }\end{array}$ & Description & Functions & Name of function \\
\hline \multirow[b]{2}{*}{ 7.1.0.4 } & \multirow{2}{*}{$\begin{array}{l}\text { The system shall manage road traffic } \\
\text { in such a way that levels of } \\
\text { environmental (i.e. atmospheric and } \\
\text { noise) pollution may be reduced. }\end{array}$} & 3.4 .8 & $\begin{array}{l}\text { Manage Environmental } \\
\text { Conditions Data Store }\end{array}$ \\
\hline & & 3.4 .11 & $\begin{array}{c}\text { Analyse Environmental } \\
\text { Data and Implement } \\
\text { Actions }\end{array}$ \\
\hline 7.1.1.6 & $\begin{array}{l}\text { The system shall be able to monitor } \\
\text { and record weather conditions (wind, } \\
\text { fog, rain level, ice, etc.). }\end{array}$ & 3.4 .1 & $\begin{array}{c}\text { Monitor Weather } \\
\text { Conditions }\end{array}$ \\
\hline \multirow{3}{*}{ 7.1.1.7 } & \multirow{3}{*}{$\begin{array}{l}\text { The system shall be able to monitor } \\
\text { and record environmental } \\
\text { (atmospheric and noise) pollution } \\
\text { conditions, and provide an alarm } \\
\text { when a certain threshold is exceeded. }\end{array}$} & 3.4 .3 & Monitor Noise Pollution \\
\hline & & 3.4 .8 & $\begin{array}{l}\text { Manage Environmental } \\
\text { Conditions Data Store }\end{array}$ \\
\hline & & 3.4 .11 & $\begin{array}{l}\text { Analyse Environmental } \\
\text { Data and Implement } \\
\text { Actions }\end{array}$ \\
\hline 7.1.1.8 & $\begin{array}{l}\text { The system shall be able to measure } \\
\text { the range of visibility and detect } \\
\text { reductions caused by adverse weather } \\
\text { and pollution conditions (but not } \\
\text { darkness). }\end{array}$ & 3.4 .2 & $\begin{array}{l}\text { Monitor Atmospheric } \\
\text { Pollution }\end{array}$ \\
\hline 7.1.2.5 & $\begin{array}{l}\text { The system shall be able to predict } \\
\text { weather conditions, in particular the } \\
\text { formation of fog and/or ice. }\end{array}$ & & \\
\hline 7.1 .2 .6 & $\begin{array}{l}\text { The system shall be able to predict } \\
\text { short, medium, and long-term road } \\
\text { travel produced environmental } \\
\text { (atmospheric and noise) pollution } \\
\text { conditions based on traffic and } \\
\text { weather conditions. }\end{array}$ & 3.4 .4 & $\begin{array}{l}\text { Predict Environmental } \\
\text { Conditions }\end{array}$ \\
\hline 7.1.5.9 & $\begin{array}{l}\text { The system shall be able to } \\
\text { recommend re-routing strategies to } \\
\text { reduce atmospheric pollution. }\end{array}$ & 3.4 .2 & $\begin{array}{l}\text { Monitor Atmospheric } \\
\text { Pollution }\end{array}$ \\
\hline
\end{tabular}


Tab. 1 List of user needs and corresponding functions (continued)

\begin{tabular}{|c|c|c|c|}
\hline $\begin{array}{c}\text { User } \\
\text { needs }\end{array}$ & Description & Functions & Name of function \\
\hline \multirow{3}{*}{ 7.5.1.3 } & \multirow{3}{*}{$\begin{array}{l}\text { The system shall be able to monitor } \\
\text { the current inter-urban traffic and } \\
\text { weather/environmental conditions, } \\
\text { identify incidents, assess their } \\
\text { impact, make short term predictions, } \\
\text { and select and initiate an appropriate } \\
\text { mitigation strategy. }\end{array}$} & 3.4 .1 & $\begin{array}{c}\begin{array}{c}\text { Monitor Weather } \\
\text { Conditions }\end{array} \\
\end{array}$ \\
\hline & & 3.4 .8 & $\begin{array}{l}\text { Manage Environmental } \\
\text { Conditions Data Store }\end{array}$ \\
\hline & & 3.4 .11 & $\begin{array}{c}\text { Analyse Environmental } \\
\text { Data and Implement } \\
\text { Actions }\end{array}$ \\
\hline 7.6.2.4 & $\begin{array}{l}\text { The system shall enable the traveller } \\
\text { information service provider to } \\
\text { receive current inter-urban traffic } \\
\text { management, and weather, } \\
\text { conditions and planned events. }\end{array}$ & 3.4 .11 & $\begin{array}{c}\text { Analyse Environmental } \\
\text { Data and Implement } \\
\text { Actions }\end{array}$ \\
\hline \multirow[b]{2}{*}{ 7.6.2.6 } & \multirow{2}{*}{$\begin{array}{l}\text { The system shall enable the traveller } \\
\text { to request and receive (anticipated) } \\
\text { weather/environmental conditions } \\
\text { on, or before, a planned trip. }\end{array}$} & 3.4 .10 & $\begin{array}{c}\text { Output Environmental } \\
\text { Information }\end{array}$ \\
\hline & & 3.4 .11 & $\begin{array}{c}\text { Analyse Environmental } \\
\text { Data and Implement } \\
\text { Actions }\end{array}$ \\
\hline
\end{tabular}

After selecting user needs and corresponding functions, we were able to move on to the issues associated with selecting data flow and the system's external links.

\section{The selection of data flows and terminators}

The terminators were determined precisely by the type of data, which shall be exchanged with them.

The following actors were selected:

- esp.ttip - Traffic and Travel Information Provider - thanks to which road users will be able to obtain information about road traffic and travel information,

- ors.etms - Environmental Traffic Management System - should enable the exchange of data ,e.g. with a system belonging to another Environmental Protection Service or with a system ensuring environmental management in another geographic area [3],

and terminators:

- ae - Ambient Environment - is a physical unit, which can provide data regarding weather conditions, such as snow, rain, fog and air pollution effects such as smoke, dust,

- $\mathrm{d}$ - Driver - a terminator representing a human individual, which is driving a licensed vehicle at any location in the road network,

- $\mathrm{t}$ - Traveller - a human individual using transport services provided by the system. A terminator can be a pedestrian, cyclist, car passenger,

- ws - Weather Systems - is a terminator providing general information in the field of weather and weather forecasts [3]. 
Impact of FRAME architecture on road traffic safety management Wplyw zastosowania architektury FRAME na zarzadzanie bezpieczeństwem ruchu..

Table no. 2 lists connections between function, data repositories and terminators.

Tab. 2 Data flows, flow sources and outflows.

\begin{tabular}{|l|l|l|}
\hline Acronym & Parent & Target \\
\hline fae-atmospheric_pollution_inputs & ae & 3.4 .2 \\
\hline fae-noise_inputs & ae & 3.4 .3 \\
\hline fae-weather_inputs & ae & 3.4 .1 \\
\hline fws-weather_data & ws & 3.4 .1 \\
\hline mt_atmospheric_pollution_data_inputs & 3.4 .2 & 3.4 .8 \\
\hline mt_confirm_environmental_actions & 3.4 .7 & 3.4 .11 \\
\hline mt_confirmed_environmental_actions & 3.4 .11 & 3.4 .8 \\
\hline mt_environmental_conditions_data_for_predictions & 3.4 .8 & 3.4 .4 \\
\hline mt_environmental_conditions_operator_requests & 3.4 .7 & 3.4 .8 \\
\hline mt_environmental_conditions_operator_responses & 3.4 .8 & 3.4 .7 \\
\hline mt_environmental_conditions_prediction_store_data & 3.4 .4 & 3.4 .8 \\
\hline mt_environmental_conditions_static_data_update & 3.4 .7 & 3.4 .8 \\
\hline mt_environmental_data_for_analysis & 3.4 .8 & 3.4 .11 \\
\hline mt_environmental_information & 3.4 .11 & 3.4 .10 \\
\hline mt_load_environmental_conditions_data & 3.4 .8 & $\mathrm{D} 3.3$ \\
\hline mt_noise_pollution_data_inputs & 3.4 .3 & 3.4 .8 \\
\hline mt_read_environmental_conditions_data & $\mathrm{D} 3.3$ & 3.4 .8 \\
\hline mt_request_environmental_data_analysis & 3.4 .7 & 3.4 .8 \\
\hline mt_suggest_environmental_actions & 3.4 .11 & 3.4 .7 \\
\hline mt_weather_condition_data_inputs & 3.4 .1 & 3.4 .8 \\
\hline td-environmental_information & 3.4 .10 & $\mathrm{~d}$ \\
\hline tesp.ttip-weather_conditions_information & 3.4 .11 & esp.ttip \\
\hline tors.etms-environmental_data_updates & 3.4 .8 & ors.etms \\
\hline tt-environmental_information & 3.4 .10 & $\mathrm{t}$ \\
\hline & & \\
\hline
\end{tabular}

Next, a database necessary for supporting specific functions was selected. It is a D3.3 "Environmental Data" database, which should be used within the Traffic Area Management. It contains data concerning environmental conditions over a geographical area managed by the system.

\section{Conclusions}

The paper attempts to develop a project of functional architecture for one of the main services significantly impacting the road traffic safety. Because the scope of the European ITS Framework Architecture contains many transport fields and can be a base for the development of an entire system for a selected road section, this paper shows the course of working with the Selection Tool and the results, which can be expected. 
Developing architecture is a long process; however, thanks to the distinguished functions, terminators and actors, it is possible to connect services with other ones within an entire system, thus - intelligent management of road network services.

The publication has been prepared within the framework of the project Development of Road Innovations funded by the National Centre for Research and Development and the General Directorate for National Roads and Motorways (Contract No. DZP/RID-I-41/7/NCBR/2016).

\section{References}

[1] Archer j., Z: Fundamental traffic safety issues concerning the use of intelligent transport systems, CRT, Kungliga Tekniska Högskolan, Stockholm, Sweden, 2000

[2] Chojnacki B., Kowalewski M., Pękalski A., Z: Znaczenie krajowej architektury ITS [The significane of national ITS architecture], Prace Naukowe Politechniki Warszawskiej

[3] E-FRAME Extend FRAMEwork architecture for cooperative systems: Function, Data Flow, Data Store and Terminator Descriptions, 2011

[4] The home of the FRAME architecture, E-FRAME project, European ITS Framework Architecture, Z: http://www.frameonline.net/home.htm

[5] Kamiński T., Niezgoda M., Siergiejczyk M., Oskarbski J., Z: Wpływ stosowania inteligentnych systemów transportowych na poziom bezpieczeństwa drogowego [The impact of using intelligent transport systems on road safety level], z.113, 2016

[6] Kasprzak W., Olszewski P. „Architektura informatyczna systemów ITS” [IT architecture of ITS systems]

[7] Lynette C. Goodwin, Weather Impacts on Arterial Traffic Flow, Mitretek Systems, Inc., 2002.

[8] http://www.piit.org.pl/documents/10181/659077/Dodatek ITS.pdf

[9] Lubkowski, P. \& Laskowski, D. 2015. Selected issues of reliable identification of object in transport systems using video monitoring services. In Communication in Computer and Information Science, vol. 471: 59-68. Berlin Heidelberg: Springer.

[10] Paś, J. 2015a. Selected methods for increases reliability the of electronic systems security. Journal of KONBiN 3(35)2015: 147-156.

[11] Piro G., Cianci I., Grieco L.A., Boggia G., Camarda P. 2014. Information centric services in Smart Cities. Journal of Systems and Software (88). Elseview, pp. 169-188.

[12] Siergiejczyk M., Rosiński A., Dziula P., Krzykowska K., ReliabilityExploitation Analysis of Highway Transport Telematics Systems, Journal of KONBiN 1(33) 2015 ISSN 1895-8281, DOI 10.1515/jok-2015-015, s. 177186. 
Impact of FRAME architecture on road traffic safety management

Wplyw zastosowania architektury FRAME na zarzadzanie bezpieczeństwem ruchu..

[13] Siergiejczyk M., Rosiński A., Krzykowska K., Reliability-exploitation analysis of the alarm columns of highway emergency communication system, Journal of KONBiN 2(38)2016, ISSN 1895-8281, pp. 53-76.

[14] Sumiła M. 2012. Selected aspects of message transmission management in ITS systems. International Conference on Transport Systems Telematics. Springer Berlin Heidelberg, pp. 141-147.

[15] Zając M., Świeboda J. 2015. Process hazard analysis of the selected process in intermodal transport. International Conference on Military Technologies (ICMT). IEEE, pp. 1-7.

[16] Chowdhury M. A., Sadek A. 2003. Fundamentals of Intelligent Transportation Systems Planning. Artech House ITS Library. Boston, London.

[17] Sun L., Li Y., Gao J. 2016. Architecture and Application Research of Cooperative Intelligent Transport Systems. Procedia Engineering 137 (2016). Elsevier, pp. $747-753$.

[18] Parallos A., Hernandez - Jayo U., Onieva E., Garcia Zuazola I.J. 2015. Intelligent Transport Systems: Technologies and Applications. Wiley, ISBN: 978-1-118-89478-1.

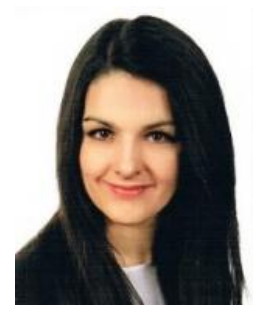

Sylwia Szewczyk, BSc., a student majoring in transport with the specialisation in Intelligent Transport Systems at the Warsaw University of Technology. (Share 20\%)

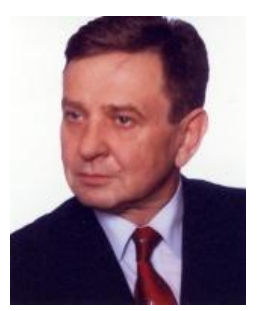

Prof. Miroslaw Siergiejczyk, PhD. Eng. - scientific fields of interest of the paper co-author concern among other issues of architecture and services provided by telecommunications networks and systems, especially from perspective of their applications in transport, reliability and operation of telecommunications networks and systems, modelling, designing and organising telecommunications systems for transport. (Share 40\%)

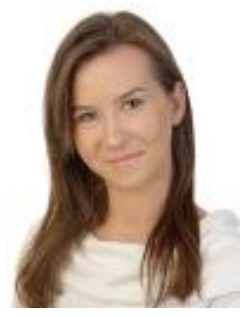

Karolina Krzykowska, MSc. Eng. - in research co-author of the article deals mainly with considerations on the reliability analysis of intelligent transport systems in the branch of road transport and aviation. She has several publications on this subject. (Share 40\%) 